\title{
10
}

\section{Social Innovation in Asia: Trends and Characteristics in China, Korea, India, Japan and Thailand}

\author{
The Hope Institute
}

\section{Introduction}

Social innovation is often defined as 'the process of inventing, securing support for, and implementing novel solutions to social needs and problems. ${ }^{2}$ Since the practice of social innovation usually tackles unmet social needs that cannot be solved solely by the government or certain stakeholders in a given society, the concept implies a unique approach to solve the social problem. As an activity or a specific case, social innovation often takes the form of collaboration across public, private and citizen

1 This chapter is based on The Social Innovation Landscape in Asia, the final report of the research that was conducted by the research team of The Hope Institute, based in Seoul, in 2013-14. The research was funded by the Rockefeller Foundation for a better and systematic understanding of social innovation practices in Asia. This chapter was presented at the conference 'Grassroots Regionalisation and the Frontiers of the Humanities in East Asia: Korea as a Hub', held by The Australian National University and was revised by one of the principal investigators, Dr EunKyung Lee, a research fellow in The Hope Institute.

2 James A. Phills Jr, Kriss Deiglmeier, and Dale T. Miller, 'Rediscovering Social Innovation', Stanford Social Innovation Review Fall (2008), ssir.org/articles/entry/rediscovering_social_innovation\#sthash. LuXlirzX.fjh2JKLM.dpuf. Accessed 20 March 2016. 
sectors, dissolving traditional boundaries. ${ }^{3}$ Implicit in the concept is the notion that its impact should be good for society and enhance society's capacity to act. ${ }^{4}$

In various parts of Asia, there has been growing interest in the processes of European and North American social innovation. Many successful social innovation cases and practices in those areas are well known. Such cases have been shared in our region-for instance, Charter Schools as an alternative educational avenue, the fair-trade movement to address indigenous farmers' labour conditions and create a sustainable environment, microfinance to include those who are unable to gain access to major financial services, and so on. However, few studies have explored the ways in which the transcultural adaptation of social innovation practices has taken place. The Hope Institute research team, with the support of Rockefeller Foundation, has investigated how social innovation practices have been put into effect in Asian countries and how they have influenced Asian societies.

In the process of compressed industrialisation after World War II, many Asian societies adopted Western-style capitalism, usually in a top-down way. Many industrialised Western social and economic practices were imposed on Asian countries. Transplanted democratic systems and unsettled civil societies characterise many Asian countries. This has led to socioeconomic malfunctioning, the underdevelopment of civil sectors, a lack of government legitimacy, and unequal access to information and technology. Given these distinct underlying conditions, it is necessary to redefine social innovation from an Asian perspective. Our task has been to collect significant cases from the Asian experience, and to analyse the characteristics of social innovation practices in Asia. In this sense, this research strongly supports the core principle that social innovation is neither context-free nor value-neutral. ${ }^{5}$

3 Geoff Mulgan, Tucker, S., Ali, R., and Sanders, B., Social Innovation: What it is, why it matters and how it can be accelerated, working paper of the Skoll Centre for Social Entrepreneurship (Oxford Said Business School, 2007) eureka.bodleian.ox.ac.uk/761/1/Social_Innovation.pdf. Accessed 30 March 2015.

4 The Young Foundation, Social Innovation Overview: A Deliverable of the Project. The Theoretical, Empirical and Policy Foundations for Building Social Innovation in Europe (TEPSIE), European Commission -7 th Framework Programme (Brussels: European Commission, DG Research, 2012), www.tepsie.eu/images/documents/TEPSIE.D1.1.Report.DefiningSocialInnovation.Part\%201\%20 -\%20defining\%20social\%20innovation.pdf. Accessed 30 March 2015.

5 The Young Foundation, Social Innovation Overview, 2012. 
This chapter presents some of the results of our research, which began with the question: Social innovation practices have had considerable success in the West. What about Asia? This seemingly simple question actually requires the demanding work of establishing a context for Asia as a region where social innovative practices are performed, as well as redefining social innovation in developing or less-developed countries. The complexity is two-fold: social innovation is a multilayered, practice-led field; and, more importantly, Asia is not a homogeneous region. Asia's diverse paths to democratisation and industrialisation add to the complexity.

Considering the context-specificity of social innovation, the research had three aims: (1) to conduct country background surveys on political, economic and social dimensions; (2) to identify social needs for such innovations, examine social innovation cases and identify their innovative features; and (3) to define common characteristics of the selected cases and identify features distinctive to Asia. This chapter focuses particularly on the third task, and so considers the following question: What are the common characteristics found in the social innovation cases in Asia?

Given the variety of social innovation ecosystems in Asia, this chapter examines whether common characteristics exist across Asian countries and how they are distinct from the Western models, which have been the main focus of international research to date. Answering this question will contribute to understanding the big picture of Asian countries' social innovation ecosystems and to examining the applicability of pre-existing projects, which mainly originated from the West, in an Asian context.

\section{Understanding Social Innovation in Asia}

This chapter begins with a review of existing definitions of social innovation. It delineates core elements and features of social innovation for research purposes. We then go on to explore how the core elements and features are adopted in Asian social innovation cases. Social innovation discussed in the Asia NGO Innovation Summit (ANIS) ${ }^{6}$ is particularly emphasised, because it has a foundational impact on the diffusion of social innovation across Asia.

6 Asia NGO Innovation Summit (ANIS) is a platform for sharing and exchanging the social innovation practices and accomplishments among social innovators in Asia. It has held annual conferences since launched in 2010 by The Hope Institute with the partnership of Intel Asia-Pacific. 
Various definitions of social innovation have been suggested and discussed by researchers, activists, policy makers and academic institutions. No commonly shared definition exists, and any search for a clear-cut, specific definition of social innovation is quickly overwhelmed by a multiplicity of contending interpretations. The diversity among social innovation definitions shows that social innovation is a practice-led, fieldspecific phenomenon. In addition, social innovation is multidimensional from the outset and covers many sectors and fields. ${ }^{7}$ The richness and openness of definitions of social innovation, however, make the debate about it hard to regulate, and it tends to fall into circular discussions. Thus, instead of attempting to pinpoint a singular definition of social innovation, for the purpose of the research, it is more appropriate to draw upon existing definitions and then to use core elements of our working definition for our selection of Asian social innovation cases presented in later sections.

Among the many definitions of social innovation, our research team particularly focused on the one used by TEPSIE ${ }^{8}$ for this study. That definition is:

Social innovations are new solutions (products, services, models, markets, processes etc.) that simultaneously meet a social need (more effectively than existing solutions) and lead to new or improved capabilities and relationships and better use of assets and resources. In other words, social innovations are both good for society and enhance society's capacity to act. ${ }^{9}$

We chose this definition for three reasons. First, while definitions used in most social innovation research are primarily drawn from academic perspectives, TEPSIE's definition embraces many aspects of experiences and decisions of social innovators and their practices. Second, it takes into consideration multiple dimensions of social innovation: the core elements, the common features, the sectors and the processes. ${ }^{10}$ Third, the TEPSIE definition has been adopted by leading social innovation researchers in the most recent studies, and thus reflects current social innovation trends.

7 The Young Foundation, Social Innovation Overview, 2012.

8 TEPSIE is a project exploring the Theoretical, Empirical and Policy foundation for Social Innovation in Europe, and it is being carried by a consortium of six partners.

9 The Young Foundation, Social Innovation Overview, 2012.

10 ibid. 


\section{Social Innovation: The Core Elements and Common Features}

The core elements listed in TEPSIE's social innovation definition are: (1) meeting a social need, (2) effectiveness, (3) novelty, (4) moving from ideas to implementation, and (5) enhancing society's capacity to act. ${ }^{11}$ In other words, social innovations are something new to the field, sector, region, market or user, and are to be applied in a new way. There should be an implementation or application of the new ideas. Such processes are explicitly designed to meet social needs in a more effective way than existing solutions for a measurable improved outcome. ${ }^{12}$ As a result, the innovation enhances society's capacity to act by developing assets and capabilities.

According to TEPSIE's study, social innovations defined by such core elements usually present the following common features. They tend to be cross-sectoral; they build new social relationships and capabilities; they are open, collaborative and experimental; they are grassroots and mutual in character; they make better use of resources; and they develop capabilities and assets. ${ }^{13}$

The core elements are defining factors of all social innovations, whereas common features of social innovations are the features found in most social innovation cases. Thus, common features are not the prerequisite elements of social innovations, but they represent the summation of various trends and approaches in social innovations practised. Distinguishing the core elements from the often-found common features of social innovations gave the research team a useful perspective. It allowed us to focus on what makes the social innovation, rather than how to implement it. In the following paragraphs, TEPSIE's five elements are presented in an Asian context, recontextualised according to the Asian social innovation environment. We applied these elements as our criteria for the selection of our Asian social innovation cases, which will be presented in a later section.

11 ibid., 18-21.

12 Jürgen Howaldt and Michael Schwarz, Social Innovation: Concepts, Research Fields and International Trends (Universitat de Barcelona, 2012), www.ub.edu/emprenedoriasocial/ca/socialinnovation-concepts-research-fields-and-international-trends. Accessed 30 June 2016.

13 The Young Foundation, Social Innovation Overview, 2012, 24. 


\section{Meeting a Social Need}

This element clarifies the goal of social innovation in any given case. We prioritised how well the social innovation case met a social need. In order to do so, we also examined each society in Asia to identify what kinds of social needs exist and which ones are urgent unmet needs. We then selected cases of social innovation that address such needs.

\section{Effectiveness}

This element focuses on the idea that social innovation should be more effective in terms of outcomes (such as quality, satisfaction, costs or impact) than existing solutions. We examined various outcomes of the selected cases in the given society or region. If the case met a social need and was an effective outcome, then the case was marked as an initial candidate in the group of Asian social innovations. As part of this process, we conducted a basic literature review, on-site and online interviews, and field visits.

\section{Novelty}

The element of novelty does not mean universal or absolute newness. It is rather the 'perceived novelty to the unit of adoption'. ${ }^{14}$ We thus tried to decide if an innovation is new in the political, social or cultural context in which the social innovation cases arise. For instance, some Asian countries in our research project are not full-fledged democratic societies, so traditional or old-fashioned Western democratic methods can be perceived as innovative or new to the people there. Thus, even if some methods are already diffused or fully adopted outside the nation or region concerned, these methods can be regarded as new or reimagined on a local level.

\section{Moving from Ideas to Implementation}

This element entails practical implementation of the idea of social innovation. Hence, even though an idea is created and experimented with, it should be applied to the field to qualify as a social innovation. This also implies that such application has to be sustainable. Adopting this

14 The Young Foundation, Social Innovation Overview, 2012. 
element, we distinguished the sustained implementation cases from onetime or temporary events or experimental cases when selecting Asian social innovation cases.

\section{Enhancing Society's Capacity to Act}

Social innovation is accomplished not only by fulfilling unmet social needs in an effective way, but also by applying the innovative process throughout society. Indeed, social innovation concerns inclusive processes involving users, beneficiaries, minorities and marginalised people in order to improve the society's capacity as a whole. Because it ultimately relates to the empowerment dimension of social innovation and societal resilience, ${ }^{15}$ this element becomes an important point, especially in the Asian context.

\section{Understanding Asia}

Asia is not a homogenous region; it includes many countries, cultures, religions and sociopolitical systems. Around 50 countries are located in Asia, and its diversity of social environment spans a greater range than any other continent in the world. While Asian nations share some common history, the level of economic and democratic advancement in the region varies dramatically, as is particularly clear when we examine Asia by subregion. There are economically advanced countries (e.g. Japan, Taiwan, Singapore, Hong Kong and South Korea), but at the same time many other countries are still suffering from severe poverty and an underdeveloped political or social system, such as dictatorship or hereditary classes. ${ }^{16}$ The diversity of the region is also reflected in both the social problems and their possible solutions.

Despite the variety of social landscapes throughout the Asian continent, some similarities emerge in the region in terms of social development and its side effects. For instance, rapid economic growth strategies, based on imported capitalism and led by a central government, are commonly found in many nations of the Asian region. This typical Asian strategy

15 Frances Westley, The Social Innovation Dynamic (University of Waterloo, 2008), sig.uwaterloo. ca/sites/default/files/documents/TheSocialInnovationDynamic_001.pdf. Accessed 14 May 2012.

16 IMF, International Monetary Fund. World Economic Outlook: Transitions and Tensions (IMF, 2013), www.imf.org/external/pubs/ft/weo/2013/02/pdf/text.pdf. Accessed 5 December 2014. 
causes a number of social problems in the region, such as a wide economic gap between the rich and the poor, oppressed civic freedom, dependency on foreign capital and political instability, etc. These problems are often addressed in Asian social innovation programs, in ways that would be less likely to be found in regions where the transitions of societal modes were relatively steady and smooth.

Some problems can be solved by applying the existing programs or models that have been successful in other regions, such as Europe or other Western countries. However, social problems that appear to be similar in nature could have very different cultural, political and social backgrounds depending on the country where the problem occurs. As a result, the replication of social innovation models that have worked successfully in other nations may be ineffective in handling social problems in an Asian country. For instance, many social innovation programs of developed countries in Europe or North America have flourished based on collaboration between the public sector and civil sector. Many nations in Asia, however, are experiencing political turmoil in the transition period, and it is not uncommon to see that Asian governments become major barriers to adopting innovative models. It is not always expected that the simple replication of successful social innovation models from Western societies would efficiently and effectively work in solving social problems in Asian countries.

Social innovation in Asia has emerged as a response to growing challenges often resulting from the 'failure' of modern welfare states and free market capitalism, and to numerous other problems beyond the current problemsolving capacity of existing institutions. ${ }^{17}$ These challenges exceed existing problem-solving capacity because they are complex, multifaceted and appear to be impossible to solve by conventional means. ${ }^{18}$ Such problems typically involve a range of stakeholders, so they must be addressed collaboratively amongst previously independent sectors such as government, civil society or private enterprises. Thus, the notion of 'social innovation' was introduced as a new way to address the challenges facing contemporary capitalist economies.

17 Example of such problems can be resource scarcity, climate change, an ageing population, impact of globalisation, impact of mass urbanisation, and so on.

18 A. Nicholls and A. Murdock eds, Social Innovation: Blurring Boundaries to Reconfigure Markets (Palgrave Macmillan, 2012). 


\section{Social Innovation Initiatives in Asia}

Social innovation is still an unfamiliar concept in Asia. Until a few years ago, there had been neither a leading government nor a civil organisation that had a social innovation vision or sought to diffuse the social innovation movement in Asia. Serious interest in Asian social entrepreneurs' activities arose partly due to the success of Grameen Bank. In addition, countless social entrepreneurs throughout the world have been learning lessons from such Asian innovators. ${ }^{19}$ But apart from these few conspicuous social enterprise models, other types of social innovation programs in Asia have not been sufficiently promoted, and little effort has been made to comprehend the landscape of Asian social innovation and its distinctive features.

It is well known that social innovation flourishes best when there is effective partnership among grassroots organisations, social innovators (who are fast, mobile, creative and practical) and sponsoring organisations (which can strategically and financially support innovative models to scale up).$^{20}$ It is obvious that new initiatives are needed to foster social innovation in Asia, but it is not clear what strategy would be appropriate to achieve this. In order to define pragmatic visions and strategies in such a challenging environment, there is a need to understand similarities and differences among the diverse nations in Asia in terms of cultural, political and social background and the overall landscape of social innovation. Our study aims to address this gap in knowledge and expertise, and build a base to understand the social innovation ecosystem in Asia. To this end, The Hope Institute in South Korea actively sought social innovation networks in Asia, by founding ANIS in 2010.

ANIS was organised to share examples and experiences among Asian social innovators. It aims to solve the social issues and problems of each nation in the region through solidarity and cooperation. In practical terms, the innovative and creative projects in the region are showcased, and the ideas and feedback from Asian social innovators are actively exchanged, while new trends in Asian social innovation are presented, discussed and forecasted through ANIS. Throughout the four years of its existence

19 The Young Foundation, Social Innovation Overview, 2012.

20 Mulgan et al., Social Innovation, 2007. 
(see Table 1), the work of ANIS has demonstrated that social innovators in Asia are groundbreakers, creating new solutions in spite of a lack of serious support from public and private sectors in a very weak civil society.

Table 1: ANIS Annual Meetings from 2009 to 2013.

\begin{tabular}{|l|l|l|l|}
\hline Stage & Annual Meeting & Theme & Participation \\
\hline Beginning & $\begin{array}{l}\text { Nov. 2009 } \\
\text { (Hope Inst. } \\
\text { \& Intel Asia } \\
\text { Agreement) }\end{array}$ & $\begin{array}{l}\text { Series of initial discussion } \\
\text { aiming at capacity- } \\
\text { building opportunity } \\
\text { for Asia NGOs }\end{array}$ & $\begin{array}{l}\text { The Hope Institute, } \\
\text { Intel Asia }\end{array}$ \\
\hline Launching & $\begin{array}{l}\text { Sept. 2010 } \\
\text { (1st, Seoul, } \\
\text { South Korea) }\end{array}$ & $\begin{array}{l}\text { Innovate, Connect } \\
\text { \& Build Asia: } \\
\text { Building Capacity } \\
\text { for Changing Asia }\end{array}$ & $\begin{array}{l}65 \text { participants, } \\
47 \text { organisations } \\
\text { from 14 countries }\end{array}$ \\
\hline Promotion & $\begin{array}{l}\text { Oct. 2011 } \\
\text { (2nd, Jeju Island, } \\
\text { South Korea) }\end{array}$ & $\begin{array}{l}\text { Promoting Social } \\
\text { Innovation in Asia: } \\
\text { Strategies and Methods }\end{array}$ & $\begin{array}{l}85 \text { participants, } \\
41 \text { organisations } \\
\text { from 14 countries }\end{array}$ \\
\hline Collaboration & $\begin{array}{l}\text { June, 2012 } \\
\text { (3rd, Seoul, } \\
\text { South Korea) }\end{array}$ & $\begin{array}{l}\text { Connect, Collaborate } \\
\text { \& Co-create Asia: } \\
\text { Collaboration across } \\
\text { Sectors for Social } \\
\text { Innovation }\end{array}$ & $\begin{array}{l}195 \text { participants, } \\
54 \text { organisations } \\
\text { from 16 countries }\end{array}$ \\
\hline $\begin{array}{l}\text { Practical } \\
\text { Solution }\end{array}$ & $\begin{array}{l}\text { Oct. 2013 } \\
\text { (4th, Bangkok, } \\
\text { Thailand) }\end{array}$ & $\begin{array}{l}\text { Social Innovation Meets } \\
\text { Technology: Scaling } \\
\text { Social Impact and } \\
\text { Enriching People's Lives }\end{array}$ & $\begin{array}{l}146 \text { participants, } \\
72 \text { organisations } \\
\text { from 16 countries }\end{array}$ \\
\hline $\begin{array}{l}\text { Shift for } \\
\text { Future }\end{array}$ & $\begin{array}{l}\text { Nov. 2014 } \\
\text { (5th, Seoul, } \\
\text { South Korea) }\end{array}$ & $\begin{array}{l}\text { Strategic Plan for } \\
\text { Future Direction }\end{array}$ & $\begin{array}{l}13 \text { participants } \\
\text { organisations } \\
\text { from } 7 \text { countries }\end{array}$ \\
\hline
\end{tabular}

Source: The Hope Institute research team.

The Hope Institute research team conducted a series of literature searches to gather information for country overviews and about numerous potential social innovation cases in selected Asian countries (China, India, Japan, South Korea and Thailand). Based on this, the research team drew up an overview of the five countries. These five countries-China, India, Thailand, South Korea and Japan-were selected based on indepth analysis of the conditions and potential of their social innovation environments. The main criteria for this selection were regional representativeness, potential for social innovation and the existence of visible social innovation cases. The team's in-depth literature searches were used to assess the preconditions for and potential of social innovation in each country, and to identify potential social innovation cases from those countries. More specific reasons for selecting each country include 
richness of cases found in a country, importance of the social innovation in a given society, and convenience to access the information and the actual fields. For instance, India was selected for having relatively rich examples of and studies on its social innovation in addition to its leading role in the region in terms of social innovation. China demonstrates high potential for social innovation but also increasing need for the role of civil society. Thailand has various social innovation projects and movements, information about which came to light at the ANIS conferences. South Korea and Japan were selected since the research team had considerable understanding of the cases of both countries, and also because a variety of cases were visible in both countries, but had so far received little attention from researchers.

For a more extensive and systematic case selection, The Hope Institute research team created the Asian social innovation case bank and clustered social innovation programs in Asia according to nations or subregions and the social issues addressed. The ANIS network was used for the case bank collection as well. The research team collected the social innovation cases through the ANIS 2012 conference meeting and conducted case surveys among the attending members. Additional Asian social innovation cases were also collected through the surveys conducted during the conference.

The research team then defined the key features and the core elements of social innovation in Asia. Using them as criteria, this study selected a total of 46 cases (China 15, India 10, Japan 6, South Korea 6, and Thailand 9) of social innovation from the five countries.

Key aspects that this research focuses on when selecting cases from each country are: 1) the case should focus less on ideological and/or theoretical issues than on practical ways of satisfying the unmet social needs in citizens' daily life; 2) the innovation should be led by citizens (in other words, by the local people who live in the region), not by social activists or politicians; and 3) cases should actually be implemented and have yielded substantial result. Key examples of social innovation in Asia include new approaches of civic participation to achieve democracy in countries with a low level of democracy and cases driven by internal forces without much external support (e.g. without the help of or direction from global nonprofit organisations or outside experts). In the case of social enterprise and government-business collaborative projects, the benefits should go to local residents and citizens at large. Other important examples are innovative projects using new technology to secure people's participation, which has been difficult to encourage otherwise. 
Data analysis was conducted through comparison, grouping and thematic categorisation, which are based on the grounded theory technique. Drawing on this analysis, we identified key elements and factors for understanding social innovation in Asia, and then identified the shared characteristics in Asian social innovations. Acknowledging that the driving force behind meaningful social change and sustainable innovation is voluntary citizen participation that bridges different sectors, the analysis focused on how different groups of people participate in the efforts to create new models for addressing social issues.

The research team conducted a series of interviews with primary players in the identified cases. A total of 45 interviews were carried out, most of them face-to-face interviews through field visits and ANIS meetings, in addition to some phone and email interviews. Interview participants were mostly social innovators, academics, organisation-based researchers (e.g. the branch offices of Ashoka Foundation, Intel China, etc.) or civic activists. The participants were recruited through the ANIS network, and additional interviews for the cases of China and India were held at the International Conference on Creativity and Innovation at Grassroots (ICCIG).

The Hope Institute research team conducted field visits to the selected countries. The field visit was one of the most important methods in this study. The main purpose was to visit the relevant organisations and collect the field information and experiences of the cases and the countries as well. During the field visits, interviews were also conducted with experts who have insights on the various countries' social issues, sectoral relations (government, business and civil society) and the role of civil society in social innovation. The networks of ANIS and Rockefeller Foundation as well as SIX (Social Innovation Exchange) served as useful initial contact points to prepare the field visits and conduct follow-up. Expert advisory conferences aimed at assessment of the social, political and economic environments of each country and the suitability of the selected cases. Advisory meetings were held either through conferencing or interview visits. The specific information on the field visits are shown in Table 2.

Many interesting innovation cases were explored in this research. Relatively successful and characteristic cases were included such as Honey Bee Network of India, focusing on small-scale technology and knowledge sharing solutions for ordinary people; Carepro, which offers an innovative approach to health services for poor and marginalised citizens in Japan; 
Hongsung Pulmu cooperative movement and the Wonju community for sustainable village development in South Korea. An interesting online ' $1 \mathrm{~kg}$ More' campaign, which carries stationery to school children in remote villages in China, was found and many active implementations of innovative social ideas by Seoul City in South Korea were included as well. Some cases are distinguished by their cross-sectoral and local government leaders' initiatives for social innovation. Information and communication technology have also become particularly important elements in social innovation, as shown in the cases of alternative political podcasts in South Korea and an online candidacy movement in China, which we studied.

Table 2: Field visits by The Hope Institute research team.

\begin{tabular}{|l|l|l|}
\hline Country & Field visits & Dates \\
\hline China & 7 & 26 November-5 December 2012 \\
\hline Hong Kong & 8 & 1-7 November 2012 \\
\hline India & 11 & $6-12$ December 2012 \\
\hline Thailand & 13 & 13-24 May 2013 \\
\hline South Korea & 6 & $1-30$ August 2013 \\
\hline
\end{tabular}

Source: Compiled by The Hope Institute research team.

\section{Seven Characteristics of Social Innovation in Asia}

The social innovation cases from the five selected countries were categorised according to trends that reflect the overall landscape and ecosystems of social innovations of the nations in Asia. The research team identified keywords from each country's social innovation trends and listed those key words based on how frequently they appeared. A word cloud tool showed 'development', 'community', 'engagement' and 'cross-sector collaboration' as the most frequent keywords (see Figure 13). This shows that social innovations in Asia revolve around the development of urban and local areas, and sustainable development in those areas, community building and citizen engagement and cross-sector collaboration to enact effective innovative approaches. 


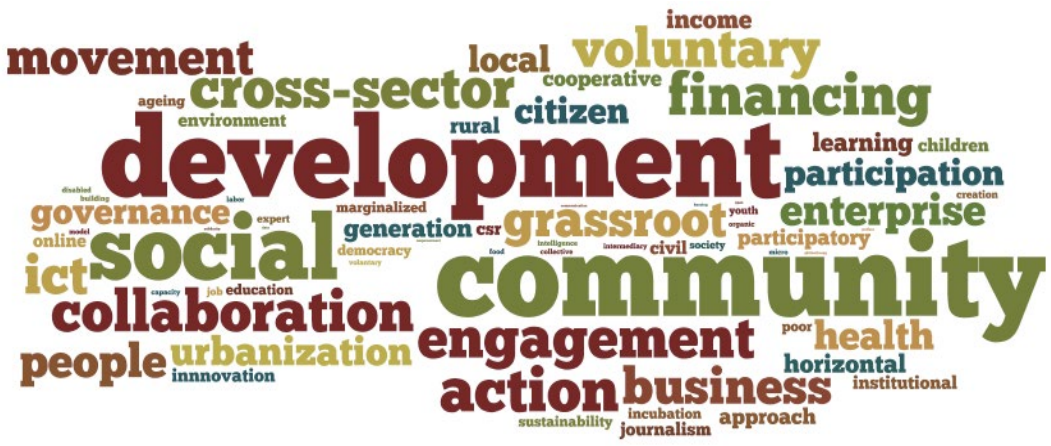

Figure 13: Keyword cloud of social innovation.

Source: The Hope Institute research team.

As another way of characterising social innovations in Asia, this study listed all the key themes and key words drawn from the country analyses, and then categorised them, using two steps. In the first step, the themes and key words were sorted according to their relevancy, and then the resulting themes were categorised into three groups-Goals, Agents and Strategies—as shown in Figure 14.

Key words/Themes

$\begin{array}{ll}\text { - Community } & \text { - Ageing } \\ \text { - People } & \text { - Post industrialism } \\ \text { - Engagement / } & \text { - Labor issue } \\ \text { participation } & \text { - Housing } \\ \text { - Local government } & \text { - Peer learning } \\ \text { - Poverty reduction } & \text { - Capacity building } \\ \text { - Rural movement } & \text { - Anti government } \\ \text { - IT application } & \text { - Quality of life } \\ \text { - Education } & \text { - Business model/mind } \\ \text { - Young people } & \text { - Entrepreneurship } \\ \text { - Social enterprise } & \text { - Social problems with } \\ \text { - Health } & \text { capitalism / } \\ \text { - Volunteerism } & \text { globalisation } \\ \text { - Governance } & \text { - Job creation } \\ \text { - Cross sector } & \text { - Free express } \\ \text { - CSR } & \text { - Children } \\ \text { - Social welfare } & \text { - Rural decline } \\ \text { - Democracy } & \text { - Urbanisation } \\ \text { - Disease } & \text { - Corruption }\end{array}$

Category I

Category II

- Increase of earnings

- Impending local issue

solving

- Everyday concerns

- Social issues solving

- Bring alternative for social

welfare problem

- Raising life quality

- People encountering the

issue

- Governments

- Intermediary organisations

- Funders

- Technology

- People engagement

- Cross-sector collaboration

- Governance

- Business model
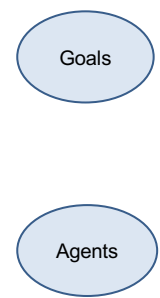

Figure 14: Two-step categorisation of keywords and themes of social innovation in Asia.

Source: The Hope Institute research team.

This figure shows that social innovation in Asia is carried out by the people directly encountering the social problems, and by governments, intermediary organisations and funders. The goals of the social innovations 
in Asia have in general targeted the tasks of increasing earnings, solving local issues, expanding social welfare services and reforming undemocratic social systems. The parties to the social innovation projects often try to achieve these goals by directly tackling such social problems and adopting technologies in an innovative way. They use cross-sectoral collaboration as a working method and apply social economy models so that the problemsolving processes can gain sustainability.

Finally, this study goes on to present seven characteristics of social innovation in Asia, as follows.

\section{People-centred Development}

One of the major characteristics of social innovation in Asia is that Asian societies face problems resulting from rapid and compressed sociopolitical development, and there is growing awareness that these problems need to be solved by the citizens by themselves. Most Asian countries have achieved some degree of economic development and democratisation. Capitalist development models and the rules of procedural democracy have been implemented. But the autonomous formation of nation-states, independent capital accumulation, the historical appearance of bourgeois and citizenry and people's awareness of citizenship have often been delayed or distorted. Though there has been considerable development through industrialisation and modernisation, the benefits have not been socially shared for sustainable development, and thus the gap between the rich and poor has deepened. According to the Asian Development Bank, the Asia and the Pacific regions remain home to the largest number of the world's poor. ${ }^{21}$ In 2008, around 63 per cent of the poor worldwide lived in the region. The number of poor people in developing member countries of Asia is 658.07 million. ${ }^{22}$ Most of them are engaged in low-waged manual labouring and lacking access to education. In particular, rural areas experience low productivity and slow technological advancement. These people also lack social welfare services, and especially suffer from poor health care.

21 Asian Development Bank (ADB), Overview of Civil Society Organisations: India (Manila: Asian Development Bank, 2009).

22 Guanghua Wan and Iva Sebastian, Poverty in Asia and the Pacific: An Update, Asian Development Bank Economics Working Paper (Manila: Asian Development Bank, 2011), 22-5. 
Such unbalanced economic and social development produces marginalised people who are excluded from the mainstream. This becomes the starting point for Asian innovators to share knowledge, information, financial resources and technology, and so to create a self-reliant economic ecosystem, which enables people to improve their social conditions for themselves. People-centred development expresses the ways in which socially aware citizens identify their own social issues and create their own solutions by actively participating in social planning and decisionmaking processes. Innovative strategies for alternative development 'of the people, by the people, and for the people' further have an impact on local and central policies. In identifying the significance of people-centred development in Asia we found two key points.

First, marginalised people themselves help to achieve their own empowerment. This is done by redefining their knowledge, creativity and the value of their experience. Networking plays a crucial role here. Through redefinition, recognition and sharing, people invent occupational or survival solutions with little reliance on official or professional expert systems. Under these circumstances, marginalised people build up an informal knowledge network connecting like-minded individuals, innovators, farmers, scholars, policy makers, entrepreneurs and NGOs to nurture creativity. For instance, India's Honey Bee Network has emphasised people-to-people learning, the 'small technology' solutions of ordinary people, and new collaborative ways to solve problems. The activities of the Honey Bee Network are connected to other organisations such as the Society for Research and Initiatives for Sustainable Technologies and Institutions (SRISTI). SRISTI is a registered charitable organisation in India, founded in 1993 in response to the need to provide systematic support to knowledge-rich but economically poor people by adding value to their creative activities. One of the interesting activities carried out by SRISTI is Shodh Yatras, which is a traditional method of learning by walking together. The practice aims to seek knowledge, creativity and innovations at grassroots through seven to 10 days of journey on foot to reach remote areas of the country. It is a journey of mutual exchange and sharing of knowledge.

Second, people-centred development focuses on the building of self-reliant alternative economic communities. While pre-existing Asian development strategies have heavily concentrated on industrialisation and urbanisation, rural areas have been degraded to become a mere source of supply of lowwaged labourers and basic food. The population and incomes of rural 
areas have rapidly shrunk. Some areas have been left devastated. In order to address such issues, farmers and local residents have created farmers' cooperatives. The cooperatives make efforts to increase members' income by setting up direct trading, adding values to products. They also make sure that part of the profits are reinvested in local improvement. ${ }^{23}$ This approach is well demonstrated in the cases of Wonju Social Economy Network and Hongsung Pulmu Village in South Korea. ${ }^{24}$

\section{Community Empowerment}

Community empowerment refers to the process of enabling communities to increase control over their lives. Community empowerment, therefore, is more than the involvement, participation or engagement of communities in developing social programs. It implies community ownership and action that explicitly aims at social and political changes. ${ }^{25}$ Community empowerment is the process of building a stronger community through skills training, capital and logistics availability and capability. In this way, the community is able to sustain livelihood or similar projects that tend to benefit the community and its constituent members. As a social innovation trend in Asia, community empowerment comes in two forms.

First, community empowerment has been carried out mainly through urban projects for slum upgrading and community rebuilding activities. Rapid industrialisation and urbanisation have resulted in the collapse of traditional communities in many places. Many Southeast Asian countries are in the course of a development process led by mega-capital investment and industrialisation. Agricultural workers are forced to become lowwaged workers in cities, and they often end up amongst the urban poor in slum areas. They frequently suffer from problems of insecure residential status. When government plans for these people proved ineffective, groups of people took the issue as their own task and came up with innovative solutions. The Bann Mankong Community Upgrade Program in Thailand

23 Kwon Seong-moon, 'A Study on Development Case in Rural Area: Focusing on Hongdong village, Hongsung County, Chungcheongnam-do' [Nongch'onjiyŏk ŭi paljŏn sarye e kwanhan yŏn'gu: Chiungnam Hongsŏnggun Hongdongmyŏn ŭl chungsim ŭro 농촌지역의 발전 사례에 관한 연구 : 충남 홍성군 홍동면을 중심으로] (Master's diss., Sungkonghoe University, 2011), 5-7.

24 Kim Heung-ju, 'A Study on Socio-economic Characteristic of Pulmu Co-op Farmers' [P'ulmusaenghyŏp saengsanja ŭi sahoegyŏngjejŏk sŏnggyŏk e kwanhan yŏn'gu 풀무생 협 생 산자의 사회경제적 성격에 관한 연구], Korean Agricultural Society 18 (2008): 45.

25 Fran Baum, 'Foreword', in Ronald Labonte and Glenn Laverack, Health Promotion in Action: From Local to Global Empowerment (London: Palgrave Macmillan, 2008), xiii-xv. 
is a good example. In this project, slum dwellers called for a forum among themselves, community groups, civil activists, community networks, civic group entrepreneurs and government officials to discuss their residential issues and potential solutions. This project was not only focused on upgrading their living conditions, but also on engaging the slum dwellers and other residents in the process. They became aware of their role and power as members of a community. In that way, this project exemplifies people-driven community development and community empowerment projects.

Second, community empowerment has been achieved by implementing self-reliant local economic ecosystems. As mentioned in the previous section, farmers' cooperatives have been promoted to create earning routes and constant reinvestment, and this has contributed to enhancing sustainability for local economies. Such autonomous systems have helped local people to raise their voices on other issues so that they can actively pursue innovative solutions. Their innovative programs for community empowerment often encounter the challenges of dominant capital. For instance, local farmers' cooperatives in South Korea often challenge the big corporations' unfair trading or interference practices. The case of consumer cooperatives in Japan, which we also examined, is somewhat different from the case of South Korea's cooperatives in that the goal of the Japanese co-ops focuses on securing everyday foodstuffs for consumers, and so does not directly target the task of raising members' income, but it does also entail activities that empower the local community. The work of these Japanese cooperatives has been centrally concerned with problems of consumers' loss of control over their own well-being, including the safety of foodstuffs. The cooperatives especially challenge big conglomerates' monopoly over the market for food and other essentials.

Most of all, community empowerment is closely connected to community rebuilding, because 'community' does not just mean the group of residents living in a region. Rebuilding community ultimately relates to building up social capital such as trust, solidarity and cooperation among members. By doing this, residents and neighbours create their own community, where their everyday concerns and economic life are shared, supported and developed. This transformation cannot be taken for granted: the residents of urban areas, members of cooperatives, local small merchants, and others people in the community are required to identify the issues 
and find out the best way to solve them. Only by such participation and struggle can the transformation of dwelling place to community be achieved.

\section{ICT-based Civic Engagement}

Information and communications technology (ICT) provides useful tools for efficient public participation in the democratic process and the dissemination of opinions and ideas. It is also frequently utilised for rallying social action about issues of concern to citizens. The technological advantages can easily be shared in societies where technological infrastructure is well established. ${ }^{26}$ In Asia, many countries are on the path to democratic transition, which has been delayed at the expense of economic development. Thus, many Asian activists adopt ICT as a strategic tool for social innovation in an environment where civil rights and civic services are severely suppressed.

ICT-based civic engagement has been made easier by advances in the ICT industry in Asian countries such as China, Hong Kong, India, Japan, South Korea and Thailand. In Asia, the internet user growth rate was 841.9 per cent for the period from 2000 to 2012. This is much faster than Europe's 393.4 per cent or North America's 153.3 per cent growth rate. ${ }^{27}$ Mobile technology has also been also rapidly popularised in Asia: the number of mobile phones per 100 citizens is 89.2 in China, 70.96 in India, 108.1 in South Korea, 95.1 in Japan and 105 in Thailand, as compared to the world average of $87 .{ }^{28}$ ICT-based civic engagement appears in two ways in Asian social innovation cases.

First, many ICT-based social innovations in Asia are related to citizens' political participation, which often encounters an authoritarian regime and/or undemocratic government policies. Some countries in this study are considered as low-ranked countries in terms of level of democracy realisation (e.g. China as an authoritarian regime; India and Thailand

26 Hong Hyojin, IT rŭl t’onghan sahoe hyŏksin sarye: Pin'gon, hwan'gyŏng, chaenan, pup'ae, chŏgaebal kukka chiwŏn, illyu ǔi nanche haegyŏl[TT를 통한 사회혁신 사례 - 빈곤 - 환경 - 재난 - 부패 · 저개발 국가 지원 · 인류의 난제 해결 Social Innovation Cases through IT: Approach for Poverty, Environment, Disaster, Corruption, International Support, Global Issues] (Seoul: National Information Society Agency, 2012).

27 www.internetworldstats.com/stats.htm. Accessed 5 December 2014.

28 en.wikipedia.org/wiki/list_of_countries_by_number_of_mobile_phones_in_use.

Accessed 5 December 2014. 
as flawed democracies). These nations are still suffering from political oppression, strict censorship and other limitations of civil rights. Countries such as Japan and South Korea are regarded as relatively highly democratised; however, there are still some oppressive political practices and limitations to civic freedom. In this social environment, ICT was actively adopted by citizen groups in order to challenge the dominant communication systems and to disseminate counter arguments and alternatives.

For example, the online candidacy movement for local elections in China from 2011 onwards was mainly carried out via SNS. The movement was initiated online to break the government's suppression of the noncommunist party members' candidacy. This case demonstrates that ICT can enable citizens to develop potential ways to promote democratic elections. Another case in South Korea, the alternative podcast broadcaster Nakomsu exemplifies the successful use of ICT for social innovation. Nakomsu effectively utilised podcast technology in order to tackle mainstream media power. It successfully played the role of a political critic of the existing regime's unethical and unjust conduct. Such cases imply that democratic improvement and enhancement of civic society are still pressing needs for many Asian societies, and that ICT can become a useful strategic tool for social innovators to address these issues.

Second, the handy and accessible features of ICT facilitate people's participation and civic awareness. The fast speed of internet and/or mobile communications prompts the dissemination of civic discourse, argument and discussion. It helps to lead less-informed people, or those who are reluctant to express their opinions in public, into more active civic engagement. Cases like ' $1 \mathrm{~kg}$ More' in China are well promoted by the ICT-based strategies, which disseminate information about their practices nationwide.

\section{Public Sector Leadership and Local Governance}

A major economic crisis beset Asia in the late 1990s. Beginning in Thailand with the collapse of the Thai baht, the financial contagion critically affected Indonesia, South Korea, Hong Kong, Malaysia, Laos and the Philippines. Though China, Taiwan, Singapore, Brunei and Vietnam were less affected, most countries experienced recession and government financial deficits. On the other hand, citizen awareness in those countries 
kept growing, while the governments faced various civic challenges including questioning of the legitimacy of regimes and of inequality, and demands for democracy and the expansion of social welfare.

Under these circumstances, Asian countries have made efforts to improve governance and to bring efficiency to governmental activities. These efforts are linked to social innovation, which is becoming a kind of global trend, as was shown by the Obama administration's establishment of an Office of Social Innovation and Civic Participation in 2009. However, few Asian countries have made such full-scale moves. Instead, the idea of 'innovation' in Asia has been approached mainly in the context of economic restructuring or goal setting. Thus 'social innovation' has not been energetically pursued as a governmental policy. However, it is acknowledged by many Asian governments as a meaningful practice that requires cross-sectoral collaboration embracing industry, civil society, and government.

Thus, many Asian governments recognise the necessity of collaboration with the civic sector. They have gradually expanded support for civil society organisations (CSOs) and developed policies and other institutional support for these organisations. For instance, the Japanese Government enacted a Non-Profit Organisation (NPO) Law in 1998, which promotes NPOs' activities and programs. Since then, more grassroots groups have been able to establish their legal status, and many local administrations have set up NPO support centres and/or various intermediaries to facilitate the provision of staff, funds and information for social innovation. China, where many civic organisations were controlled and censored, also reformed social welfare service systems so that local governments took on a greater role relative to the central government. As a result, CSOs' participation in the social welfare sector is increasing. Thailand's government set up a National Social Enterprise Committee (NSEC) under the Prime Minister's Office. The NSEC created a Social Enterprise Master Plan to support social enterprise and facilitate the incubation of various social enterprise ideas. India also established National Innovation Council and set up a National Innovation Fund in order to promote grassroots level innovations.

In addition to these supportive policy initiatives and efforts by central governments to create a favourable environment, local administrations have taken more specific actions to adopt practical social innovation policies. This reflects the fact that many Asian countries are in the course 
of decentralisation. So local governments welcome social enterprise and related innovation activities because these eventually contribute to strengthening local financial independence and effective policies, as well as promoting citizens' participation at the local level. Therefore, local governments in Asia try to seize opportunities to collaborate with civic sectors by establishing various supportive measures for community business. They also become more active in adopting participatory decisionmaking processes. The City of Seoul, South Korea, provides a good example of such engagement. In Japan, some local governments have also implemented municipal ordinances for community making to encourage local citizens' participation. Chinese governments too are putting forward social innovative programs under the banner of 'Social Management Innovation', to reinforce transparency and citizen participation.

\section{Social Entrepreneurship}

Most Asian countries have experienced rapid industrialisation and other social transformations in the short period of less than a century, or in some cases even in a few decades. This rapid industrialisation has caused many sociopolitical problems. Social innovation in Asia necessarily confronts such problems and seeks to address them through innovative programs. One salient approach to this is social entrepreneurship. The emergence of social entrepreneurs is, in general, seen as a consequence of the failure of the modern welfare state and/or of flaws in conventional market capitalism. In other words, social entrepreneurs have emerged to provide solutions to the issues that lie beyond the capacity of the government or market alone. However, in Asia, space for the birth of social entrepreneurs has yet to emerge. Japan and South Korea have to some extent experienced economic development followed by the introduction of social welfare measures, but there still exist unaddressed basic needs such poverty, malnutrition, disease and lack of educational opportunities in many Asian nations. In such circumstances, the emergence of social entrepreneurs in Asia tends to fill gaps in the state social welfare system itself. Social entrepreneurs often take on the tasks that have been performed by the government in traditional welfare states.

Another characteristic of Asian social innovation in relation to social entrepreneurs is that a business model is actively adopted as a means for NGOs' profit-making, or for profit-driven enterprises to promote public values. An example for this appears in the case of social enterprise in India, 
where almost 40 per cent of the population live below the national poverty line. ${ }^{29}$ In fact, approximately three-quarters of Indian social enterprises target the base of the pyramid (BOP) as consumers of critical goods and services. Those new business models rely on multitiered pricing or crosssubsidisation, which means (for example) that paying patients subsidise those who cannot afford the cost. Another example of this trend can be found in the Japanese health initiative Carepro, which provides self checkup services at low cost-about $\$ 5$. This shows how a social welfare service (health care) was taken over by a combination of the market approach and a 'public good' business model. In Japan it was possible for such a business model to appear in social services mainly as a result of social welfare system reform: a long-term care insurance scheme was created, and this allowed NPOs and other cooperatives to enter service areas such as human care and long-term care service for the elderly people.

The proliferation of social enterprise in Asia is also related to the ups and downs of CSOs. Gradual democratisation and the growth of the middle class contributed to an increase of CSOs as well. However, those civic organisations soon faced hard times in terms of financial sustainability when economic recession arrived. Many non-profit organisations changed into social enterprises to find better opportunities for self-financing, and this change was also encouraged by government policies to support social enterprise. In China, almost 20 per cent of social enterprises are actually registered as CSOs and thus there is no clear distinguishing line between the two forms of program. It should also be noted that the global rise of social enterprise, particularly successful examples such as Grameen Bank, influenced many young entrepreneurs to move in this direction. Young professionals who have experience of working in industries also often move into social venture and related areas (e.g. social impact investment).

29 Melissa Ip, 'Exploring India's Social Enterprise Landscape', Social Enterprise Buzz, 19 April 2012, www.socialenterprisebuzz.com/2012/04/19/exploring-indias-social-enterpriselandscape/. Accessed 1 December 2014. 


\section{Intermediary Organisations}

Intermediary organisations ${ }^{30}$ provide support financially and policywise. Thus, they help to create the environment for social innovation. In fact, many cases selected for this study displayed the importance of the intermediaries. The Honey Bee Network in India is a good example in that the network has led many grassroots innovations. It successfully created various projects to facilitate indigenous knowledge, experience and creativity.

In the cases of China and Thailand, intermediaries played a crucial role in the development of social enterprise. In particular, intermediaries such as the British Council and the Ashoka Foundation introduced the concept of social enterprise and actively spread its outcome by holding competitions and forums. ${ }^{31}$ They also connected social enterprises to funding bodies and expanded opportunities for various social enterprises to implement their ideas. Moreover, intermediaries have played an important role when Asian governments embarked on supporting social innovations. The case of City of Seoul in South Korea illustrates this: the city promoted social innovation more effectively by utilising various intermediary organisations (e.g. a hub for young job-seekers, a creativity lab, a centre for local community support, centres for youth like the innovative Haja Center, also mentioned in Chapter Seven, which provides education for young people seeking an alternative from the standard school system, and so on).

When civil society is sufficiently developed to stand alone as a partner in collaboration with government in Asia, intermediaries play an important role to connect the two sectors. This has been done by way of education, enhancement programs, grassroots empowerment, etc.

30 Intermediary organisations play a fundamental role in encouraging, promoting and facilitating linkage between state/local governments and non-governmental organisations (NGOs, NOPs, community groups, civic groups, academic institutions and private corporations). Infrastructure organisation, umbrella organisation, local development agency, intermediary support organisation are the terms to identify such role and actitivity in the countries like the US, UK and Japan.

31 Ashoka Foundation. Ashoka innovators for the public: Prayong Doklamyai, 2012, www.ashoka. org/fellow/prayong-doklamyai. Accessed 30 October 2012. 


\section{Cross-sectoral Partnership}

Social innovation is cross-sectoral by nature; it is often achieved through partnerships and collaborations among four sectors: the non-profit, public, private and informal sectors. Asian social innovations too display 'more than one sector' collaboration, though there are variations in the role of the various sectors. However, as pointed out in the previous section, the civic or non-profit sector in Asia has not been strong enough to lead the partnership. In addition, some governments too lack strong governance. Under these circumstances, Asian social innovation is characterised by the active role of informal participants and their leading contribution to cross-sectoral collaboration. Notably, professional experts (professors, scientists, engineers, architects, medical doctor, etc.) made up much of this informal sector, and their participation has contributed to the success of many social innovation cases. For instance, architects played an important role in the Residential Innovation Project in Thailand. These architects were closely connected to the project and held housing design workshops in addition to their consulting tasks. Most of the grassroots innovations in India have been based on the participation of scientists, engineers and IT professionals, who provide practical support such as the enhancement of farm equipment and agricultural production processes. Their contributions are not limited to simple volunteering; they become a kind of pro bono work, in that their professional abilities serve social goals and contribute to public services. This kind of informal sector plays a crucial role in enabling social innovation to come up with practical solutions and to sustain social innovation practices in Asian context where the number of social innovators is still small.

\section{Conclusion}

Social innovation is defined as a process whereby all sectors in a society, namely, the government, business and citizen, join in collaborative efforts to address issues facing the society. The mainstream discourse of social innovation that emerged from Western society stresses the importance of innovative ways of cooperation among different social sectors to meet social needs. In addition, it emphasises the sustainability of society and voluntary citizen participation. However, the contexts of Asia are quite different. Many countries in Asia demonstrate 'weak governance' with a low level of government transparency and accountability, which means 
that the government has a lack of capacity to deal with social problems in trusted and transparent ways. This is often coupled with a shortage of available finance. The majority of Asian countries suffer from a democracy deficit, which is clearly one of the key barriers to citizen participation in addressing pressing social challenges. Asian citizens are still struggling with poverty, public health, problems of a wide gap between rich and poor, restricted civil rights and dictatorship. Compressed development and top-down industrialisation through government-driven strategies have caused many of the existing problems. Asian countries have to cope in their own way with crucial social needs in order to improve daily lives and promote democratisation and civil liberty.

However, this does not mean that Asian societies are not ready for social innovation. Rather, because of these multilayered problems, social innovation projects are crucial in Asian societies. Many cases from the five countries we studied demonstrate how effectively social innovation projects contribute to citizen awareness, bottom-up action, self-reliant business, the pursuit of civil liberty and community rebuilding. Asian social innovation often overlaps with social movements and/or democratic reform. Social innovation in Asia on the one hand presents 'continuity' from sociopolitical democratisation movements, which are based on grassroots, bottom-up civic action. On the other hand, the innovation movement implies 'discontinuity' from the conventional movements, such as class-based political struggles, hierarchical forms of resource mobilisation or ideology-centred activism. It is problematic to identify the social innovation movement of Asia simply in terms either of continuity or of discontinuity from earlier social movements. There is much scope here for further discussion and follow-up research on this burgeoning area of social action. 
This text is taken from New Worlds from Below: Informal life politics and grassroots action in twenty-first-century Northeast Asia, edited by Tessa Morris-Suzuki and Eun Jeong Soh, published 2017 by ANU Press, The Australian National University, Canberra, Australia. 